\title{
Przeżycia chorych na raka krtani leczonych napromienianiem w latach 2003-2006 w Samodzielnym Publicznym Zakładzie Opieki Zdrowotnej Ministerstwa Spraw Wewnętrznych z Warmińsko-Mazurskim Centrum Onkologii w Olsztynie
}

\author{
Karolina Osowiecka , Monika Rucińska1,2, Sergiusz Nawrocki³
}

\begin{abstract}
Wstęp. Nowotwory głowy i szyi stanowią w Polsce około 6\% wszystkich zachorowań na nowotwory złośliwe. Najczęstszym wśród nich jest rak krtani. Celem analizy była ocena skuteczności leczenia chorych na raka krtani w Samodzielnym Publicznym Zakładzie Opieki Zdrowotnej Ministerstwa Spraw Wewnętrznych z Warmińsko-Mazurskim Centrum Onkologii w Olsztynie (SP ZOZ MSW z W-MCO w Olsztynie) prowadzonego w latach 2003-2006 (pierwsze 4 lata działalności ośrodka).
\end{abstract}

Materiał i metody. Analizą objęto wszystkich pacjentów (220) leczonych napromienianiem z powodu raka krtani w latach 2003-2006 (w stopniu klinicznego zaawansowania I-IV, leczonych radykalnie i paliatywnie). Przeżycia całkowite chorych oszacowano za pomocą metody Kaplana-Meiera. Przeżycie w podgrupach porównano przy użyciu testu log-rank (wyniki mają ograniczoną wartość ze względu na retrospektywny charakter analizy).

Wyniki. Dwu- i pięcioletnie przeżycia całkowite (OS) wszystkich 220 chorych wyniosły 57\% i 43\% (mediana przeżyć: 3 lata i 2 miesiące). Dwu- i pięcioletnie OS osób leczonych z założeniem radykalnym wyniosły: 65\% i 48\% (mediana przeżyć - prawie 5 lat). Dwu- i pięcioletnie OS pacjentów, u których zastosowano samodzielną radioterapię i radioterapię pooperacyjną, wyniosły odpowiednio 74\% i 53\% oraz 63\% i 50\%. Dwu- i pięcioletnie OS chorych, u których zastosowano samodzielną radioterapię w stopniu klinicznego zaawansowania I-II i III-IV, wyniosły odpowiednio 79\% vs $45 \%$ i $59 \%$ vs $18 \%(p=0,004)$. Dwu- i pięcioletnie OS osób, u których zastosowano leczenie operacyjne i uzupełniającą radioterapię w stopniu zaawansowania klinicznego I-II i III-IV, wyniosły odpowiednio: 87,5\% vs 60\% i 87,5\% vs 46\%. Pięcioletnie OS pacjentów z cechą N0, u których zastosowano samodzielną radioterapię, wyniosły 57\%; nikt spośród osób z cechą N1-3 nie przeżył 5 lat. Dwu- i pięcioletnie OS pacjentów z cechą N(-) i N(+), leczonych operacyjnie z uzupełniającą radioterapią, wyniosły odpowiednio: $75 \%$ vs 50\% i 59\% vs $40 \%$ ( $p=0,22)$. Nie wykazano istotnych statystycznie różnic w OS chorych leczonych radioterapią standardową i hypofrakcjonowaną. Spośród pacjentów leczonych z powodu pooperacyjnej wznowy miejscowej lepiej rokują chorzy ze wznową późną.

Podsumowanie. Przeżycia całkowite pacjentów leczonych z powodu raka krtani w niższym stopniu klinicznego zaawansowania i osób z cechą N(-) były znamiennie dłuższe w porównaniu z OS chorych w stopniach wyższych.

\section{1'Zakład i Oddział Radioterapii}

Samodzielny Publiczny Zakład Opieki Zdrowotnej

Ministerstwo Spraw Wewnętrznych z Warmińsko-Mazurskim

Centrum Onkologii w Olsztynie

${ }^{2}$ Katedra Onkologii

Wydział Nauk Medycznych, Uniwersytet Warmińsko-Mazurski w Olsztynie

${ }^{3}$ Katedra Onkologii i Radioterapii

Śląski Uniwersytet Medyczny 


\section{Survival of patients treated with radiation for laryngeal cancer in the Hospital of the Ministry of Interior with Warmia and Mazury Oncology Center in Olsztyn between 2003 and 2006}

Introduction. In Poland, head and neck cancer accounts for some $6 \%$ of all cancer cases. The most common cancer in this group is cancer of the larynx. The aim of this study was the estimation of treatment effectiveness of patients treated for laryngeal cancer in the Hospital of the Ministry of Interior with Warmia and Mazury Oncology Center in Olsztyn between 2003 and 2006 (the initial 4 years of the Centre's activity).

Material and methods. The analysis included all patients (220) treated with radiation for laryngeal cancer between 2003 and 2006 (I-IV clinical stages, treated with radical and palliative radiotherapy). The Kaplan-Meier method was used to estimate overall survival. Differences in survival of subgroups were evaluated using the log-rank test: but the results have limited value due to retrospective rather than prospective analysis.

Results. Overall 2-year and 5-year survival (OS) of all 220 patients was $57 \%$ and $43 \%$ (median 3 years and 2 months). 2-year and 5-year OS of patients treated with radical intent was $65 \%$ and $48 \%$ (median of almost 5 years). 2 -year and 5 -year OS of patients treated with radiotherapy alone and postoperative radiotherapy were respectively $74 \%$ and $53 \%, 63 \%$ and 50\%. 2-year and 5-year OS of patients in I-II and III-IV clinical stages treated with radiotherapy alone was respectively: $79 \%$ vs $45 \%$ and $59 \%$ vs $18 \%$. $(p=0.004)$. 2-year and 5 -year OS of patients in I-II and III-IV clinical stages treated with postoperative radiotherapy was respectively: $87.5 \%$ vs $60 \%$ and $87.5 \%$ vs $46 \%$. 5 -year OS of patients with N0 treated with radiotherapy alone was $57 \%$. None of patients with N1-3 has survived 5 years. 2-year and 5-year OS of patients with $\mathrm{N}(-)$ and $\mathrm{N}(+)$ treated with postoperative radiotherapy was respectively: $75 \%$ vs $50 \%$ and $59 \%$ vs $40 \%(p=0.22)$. There were no statistically significant differences between the OS of patients treated with standard and hyperfractionated irradiation. Survival of patients treated with radiation for postoperative late relapse was better than the OS of patients treated for postoperative early relapse.

Conclusions: Overall survival of patients with less advanced disease and patients with N(-) was significantly longer than the OS of patients with advanced laryngeal cancer.

Słowa kluczowe: rak krtani, radioterapia, radiochemioterapia, radioterapia pooperacyjna, 2-letnie i 5-letnie przeżycia całkowite

Key words: laryngeal cancer, radiotherapy, chemoradiotherapy, postoperative radiotherapy, 2- and 5-year overall survival

NOWOTWORY Journal of Oncology 2014; 64, 3: XXX-XXX

\section{Wstęp}

Nowotwory głowy i szyi stanowią w Polsce około 6\% wszystkich zachorowań na nowotwory złośliwe. Najczęstszym wśród nich jest rak krtani (stanowi około 3\% wszystkich zachorowań na nowotwory złośliwe). Rak krtani występuje 7-krotnie częściej u mężczyzn niż u kobiet (stanowi 2,75\% wszystkich zachorowań na nowotwory złośliwe u mężczyzn i 0,39\% u kobiet). Jest on przyczyną 2,6\% wszystkich zgonów z powodu nowotworów złośliwych u mężczyzn i 0,4\% u kobiet [1].

Celem niniejszej analizy była ocena skuteczności leczenia chorych na raka krtani w Samodzielnym Publicznym Zakładzie Opieki Zdrowotnej Ministerstwa Spraw Wewnętrznych z Warmińsko-Mazurskim Centrum Onkologii w Olsztynie (SP ZOZ MSW z W-MCO w Olsztynie) prowadzonego w latach 2003-2006 (pierwsze 4 lata działalności ośrodka).

\section{Materiał i metody}

Analizą objęto wszystkich chorych z rozpoznaniem raka krtani leczonych napromienianiem w SP ZOZ MSW z W-MCO w Olsztynie w latach 2003-2006. W tej grupie znaleźli się pacjenci w różnym stopniu zaawansowania klinicznego (I-IV wg klasyfikacji TNM-UICC/AJCC 2003 rok), leczeni z intencją radykalną i paliatywną. Chorzy leczeni napromienianiem z intencją radykalną otrzymali radioterapię lub radiochemioterapię jako leczenie samodzielne bądź pooperacyjne. Uwzględniono także osoby napromieniane z powodu wznowy miejscowej po uprzednim leczeniu operacyjnym.

Baza danych Lantis, wykorzystywana w Zakładzie Radioterapii SP ZOZ MSW z W-MCO w Olsztynie, posłużyła do wygenerowania listy chorych leczonych napromienianiem z powodu raka krtani. Dane o śmierci pacjentów uzyskano z Warmińsko-Mazurskiego Rejestru Nowotworów w Olsztynie oraz z Centrum Personalizacji Dokumentów Ministerstwa Spraw Wewnętrznych Wydziału Udostępniania Danych w Warszawie. Pozostałe dane wykorzystane do analizy pochodziły z dokumentacji medycznej (historia choroby) oraz z bazy danych Lantis. Sporządzono bazę danych w programie STATISTICA (wersja 10; 2012 r.). Za pomocą tego oprogramowania przeprowadzono analizy przeżyć pacjentów, mierzone od daty rozpoczęcia radioterapii do daty ostatniej obserwacji (śmierci). Analiza przeżycia zo- 
stała przeprowadzona z wykorzystaniem metody Kaplana-Meiera, a istotność statystyczna różnic pomiędzy grupami była oceniana testem log-rank. Za statystycznie znamienne przyjęto wartości $p \leq 0,05$.

\section{Wyniki}

W latach 2003-2006 w SP ZOZ MSW z W-MCO w Olsztynie leczono napromienianiem 220 pacjentów chorych na raka krtani. W analizowanej grupie było 35 kobiet (16\%) i 185 mężczyzn (84\%). Rozpiętość wieku leczonych osób była duża (39-87 lat). Kobiety były nieco młodsze niż mężczyźni (kobiety: 45-77 lat, średnia wieku 58 lat, mediana 55 lat, odchylenie standardowe SD = 9,34 roku; mężczyźni: 39-87 lat, średnia wieku 61,5 roku, mediana 60 lat, odchylenie standardowe $\mathrm{SD}=10,47$ lat) (rycina $1 \mathrm{~A}$ i B - tylko w wersji elektronicznej).

Większość chorych z rozpoznaniem raka krtani leczonych w tutejszym ośrodku w latach 2003-2006 otrzymało leczenie z intencją radykalną (193 pacjentów, 88\%) (tab. I). Najwięcej osób leczonych napromienianiem z założeniem radykalnym (77 pacjentów, 40\%) było w IV stopniu zaawansowania klinicznego nowotworu (z cechą M0), natomiast 47 pacjentów (24\%) - w stopniu I (tabela II — tylko w wersji elektronicznej). Większość chorych leczonych radykalnie nie miała zajętych węzłów chłonnych (129 pacjentów, 67\%) (tabela III — tylko w wersji elektronicznej). Nie zaobserwowano statystycznej różnicy w odsetkach leczonych radykalnie zależnej od płci: 33 pacjentki spośród 35 kobiet chorych na raka krtani (94\%) i 160 pacjentów spośród 185 mężczyzn chorych na raka krtani (86\%) poddanych zostało napromienianiu z intencją radykalną.

Dziewięćdziesiąt dwie osoby (48\% wszystkich osób leczonych z intencją radykalną) były poddane leczeniu operacyjnemu, a następnie samodzielnej radioterapii (86 pacjentów; $45 \%$ leczonych radykalnie) lub radiochemioterapii (6 pacjentów; 3\% leczonych radykalnie) (tab.l).Dwie trzecie osób leczonych napromienianiem po operacji (63 pacjentów; $68 \%$ ) było w IV stopniu zaawansowania klinicznego, połowa chorych (48 pacjentów; 52\%) miała zajęte węzły chłonne.

Osiemdziesiąt cztery osoby (43\% wszystkich pacjentów leczonych z intencją radykalną) nie były poddane operacji, a otrzymały wyłącznie samodzielną radioterapię (72 pacjentów; 37\% leczonych radykalnie) lub radiochemioterapię (12 pacjentów; 6\% leczonych radykalnie) (tab. I). Prawie połowa osób, którzy otrzymali napromienianie bez uprzedniej operacji (35 chorych; 41,5\%), była w I stopniu zaawansowania klinicznego, 26 pacjentów (31\%) było w Il stopniu zaawansowania klinicznego i większość chorych (73 chorych; 87\%) nie miała zajętych węzłów chłonnych.

W sumie u 18 pacjentów skojarzono radioterapię z chemioterapią (1-3 kursy cisplatyny podane $w$ trakcie radioterapii), w tym 6 chorych (3\% pacjentów leczonych radykalnie) otrzymało radiochemioterapię pooperacyjną.
Tabela I. Sposób leczenia (220 pacjentów)

\begin{tabular}{lcc}
\hline Sposób leczenia & Liczba & $\%$ \\
\hline Wszyscy pacjenci & 220 & 100 \\
Leczenie radykalne & 193 & 88 \\
Radioterapia samodzielna & 72 & 37 \\
Radiochemioterapia & 12 & 6 \\
Radioterapia samodzielna pooperacyjna & 86 & 45 \\
Radiochemioterapia pooperacyjna & 6 & 3 \\
Radioterapia samodzielna wznowy miejscowej & 7 & 4 \\
Radiochemioterapia wznowy miejscowej & 10 & 5 \\
Radioterapia paliatywna & 27 & 12 \\
\hline
\end{tabular}

Siedemnastu chorych ( $9 \%$ wszystkich pacjentów leczonych z intencją radykalną) otrzymało napromienianie z powodu wznowy miejscowej po operacji, z czego 6 osób z powodu wznowy miejscowej wczesnej (1-3 miesiące po operacji) i 11 osób z powodu wznowy miejscowej późnej (1-8 lat po operacji), w tym 7 chorych otrzymało radioterapię, a 10 - radiochemioterapię. Dwóch pacjentów z 10 osób poddanych radiochemioterapii z powodu wznowy miejscowej otrzymało 2 kursy chemioterapii indukcyjnej (cisplatyna + 5-fluorouracyl) (tab. I).

Radioterapię przeprowadzono przy użyciu fotonów o energii 6 MV uzyskanych w akceleratorze liniowym. Stosowano planowanie leczenia 3D. Większość osób leczonych radykalnie (155 chorych, 80\%) otrzymała 60-74 Gy w 30-37 frakcjach po 2 Gy, w tym 116 chorych (60\% leczonych radykalnie) otrzymało 60-66 Gy w 30-33 frakcjach (2 pacjentów nie otrzymało ostatniej frakcji z powodu odmowy kontynuacji leczenia). Dwie osoby otrzymały $66,6 \mathrm{~Gy}$ w 37 frakcjach w dawce frakcyjnej 1,8 Gy. Trzydziestu dwóch pacjentów (17\% leczonych radykalnie) otrzymało 50-61 Gy w 18-25 frakcjach po 2,5 Gy lub 3 Gy. U 4 chorych leczonych z założeniem radykalnym we frakcjonacji po 2 Gy przerwano leczenie $z$ powodu pogorszenia stanu ogólnego i/lub nasilonych powikłań ostrych na dawce odpowiednio: $16 \mathrm{~Gy}$, $40 \mathrm{~Gy}, 46 \mathrm{~Gy}$ i $50 \mathrm{~Gy}$.

Całkowity czas trwania leczenia z założeniem radykalnym (od początku radioterapii do jej zakończenia) wyniósł 1,4-8 tygodni (mediana 6,3 tygodnia, średni czas 6 tygodni, odchylenie standardowe 0,96 tygodnia). W przypadku radiochemioterapii radioterapię rozpoczynano z pierwszym kursem chemioterapii.

\section{Analiza przeżyć}

Spośród 220 chorych leczonych napromienianiem z powodu raka krtani w latach 2003-2006 w tutejszym ośrodku 146 pacjentów zmarło, 74 pacjentów żyje nadal. Dwuletnie przeżycia całkowite (OS) dla wszystkich chorych leczonych z powodu raka krtani (radykalnie i paliatywnie) wyniosły 57\%, 5-letnie przeżycia całkowite wyniosły 43\% (mediana 


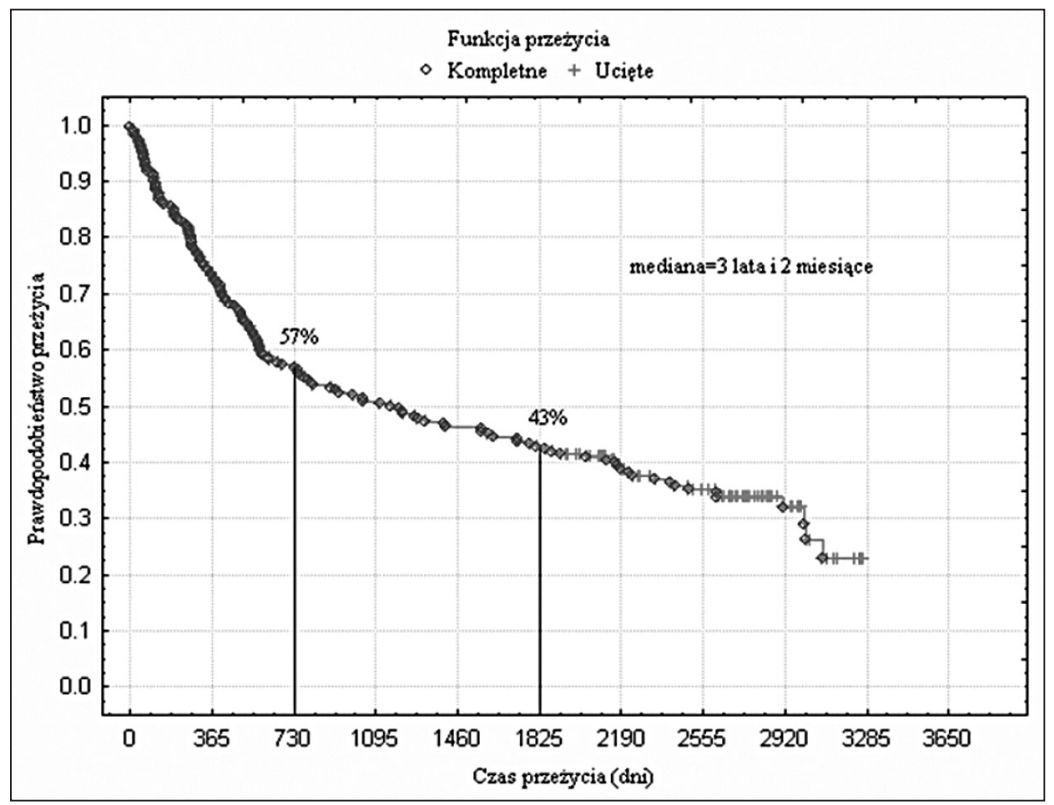

Rycina 2. Krzywa przeżycia całkowitego wszystkich 220 pacjentów

przeżyć 3 lata i 2 miesiące) (ryc. 2). Dwuletnie przeżycia całkowite pacjentów leczonych z założeniem radykalnym wyniosły 65\%, 5-letnie przeżycia całkowite wyniosły 48\% (mediana przeżyć 4 lata i 9 miesięcy) (rycina 3 - tylko w wersji elektronicznej).

Nie wykazano różnic w przeżyciach całkowitych zarówno 2- jak i 5-letnich pomiędzy kobietami i mężczyznami leczonymi z intencją radykalną (różnice pomiędzy tymi grupami nie są znamienne statystycznie; $p=0,69$ ). Mediana przeżyć kobiet (6 lat i 7 miesięcy) jest jednak dłuższa niż mężczyzn (4 lata i 4 miesiące).

Nie wykazano istotnych statystycznie różnic w przeżyciach pacjentów leczonych radykalnie metodą standardową (w dawce frakcyjnej $2 \mathrm{~Gy}$ ), a hypofrakcjonowaną (w dawce frakcyjnej 2,5-3 Gy) (test log-rank; p = 0,22). Zauważono tendencję do wydłużania OS w przypadku stosowania hypofrakcjonacji (nie osiągnięto mediany przeżycia). Trudno retrospektywnie jednoznacznie określić kryteria doboru pacjentów do tych dwóch sposobów frakcjonowania. Prawdopodobnie pacjenci, którzy otrzymywali leczenie w dawce większej niż 2 Gy, byli w niższym stopniu klinicznego zaawansowania choroby. Pacjenci leczeni z założeniem radykalnym, którzy nie ukończyli zaplanowanej radioterapii, umierali w ciągu kilkunastu miesięcy.

Chorzy, którzy otrzymali pooperacyjną radiochemioterapię z powodu histopatologicznie potwierdzonej obecności przerzutów do regionalnych węzłów chłonnych (6 osób w stadium klinicznego zaawansowania III-IV), szczególnie źle rokowali na tle wszystkich pacjentów leczonych z założeniem radykalnym (mediana przeżyć pacjentów z cechą $\mathrm{N}(+)$ wyniosła pół roku, przy medianie przeżyć wszystkich chorych leczonych radykalnie sięgającej prawie 5 lat). Powo- dem wczesnych zgonów tych osób mogło być duże zaawansowanie choroby i/lub powikłania leczenia. U 12 pacjentów w stadium klinicznego zaawansowania III-IV (w tym u 6 chorych z cechą $\mathrm{N}(+)$ i u 6 chorych z cechą $\mathrm{N}(-)$ potwierdzoną badaniami obrazowymi) zastosowano jedynie radiochemioterapię. Mediana przeżyć pacjentów leczonych wyłącznie metodą skojarzonej radioterapii i chemioterapii, którzy nie mieli zajętych węzłów chłonnych, była znacznie dłuższa, i wyniosła 8,5 roku w porównaniu z medianą przeżyć osób z cechą $\mathrm{N}(+$ ) sięgającą 1 roku (różnice pomiędzy tymi grupami są znamienne statystycznie; $p=0,028$ ). Pięcioletnie OS pacjentów w zaawansowanym stopniu klinicznym z cechą $\mathrm{N}(+)$ poddanych operacji i radiochemioterapii uzupełniającej oraz samodzielnej radiochemioterapii wyniosły 17\%, natomiast OS chorych z cechą N(-) poddanych samodzielnej radiochemioterapii wyniosło $83 \%$.

Przeprowadzono analizę przeżycia całkowitego dla grupy chorych leczonych z intencją radykalną, którzy otrzymali samodzielną radioterapię bez operacji i po jej przebyciu. Nie wykazano różnic pomiędzy tymi grupami. Dwu- i pięcioletnie przeżycia całkowite pacjentów, u których zastosowano samodzielną radioterapię, wyniosły odpowiednio 74\% i 53\% (mediana przeżyć 5 lat i 11 miesięcy), zaś u osób, które otrzymały radioterapię pooperacyjną, odpowiednio $63 \%$ i 50\% (mediana przeżyć 5 lat) (ryc. 4).

Przeprowadzono analizę porównawczą pacjentów leczonych radykalnie, różniących się stopniem klinicznego zaawansowania. Wykazano, że chorzy z niższym stopniem klinicznego zaawansowania nowotworu rokują lepiej. W przypadku osób leczonych jedynie samodzielną radioterapią 2- i 5-letnie przeżycia całkowite w stopniu zaawansowania klinicznego I-Il wyniosły odpowiednio 79\% i 59\% 


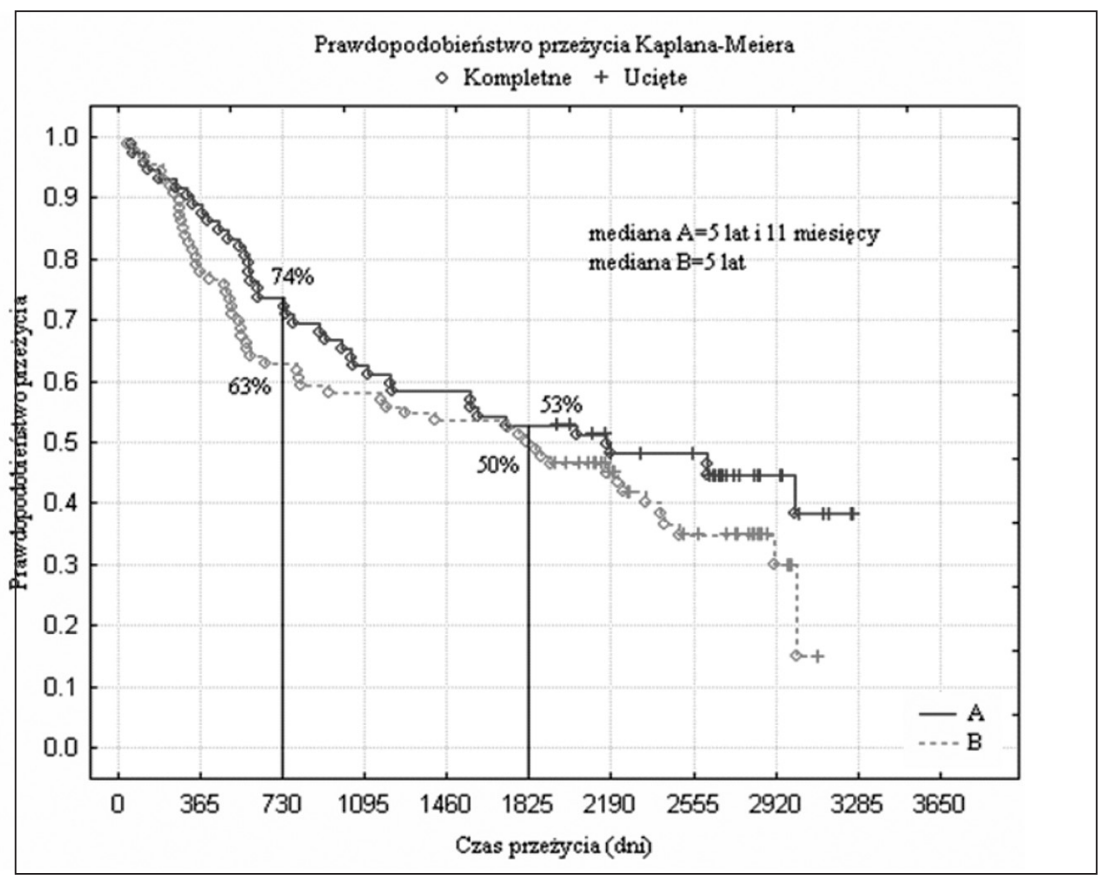

Rycina 4. Krzywe przeżycia całkowitego dla osób leczonych radykalnie (A - 72 pacjentów, u których zastosowano samodzielną radioterapię, B - 86 pacjentów, u których zastosowano operację z uzupełniającą radioterapią)

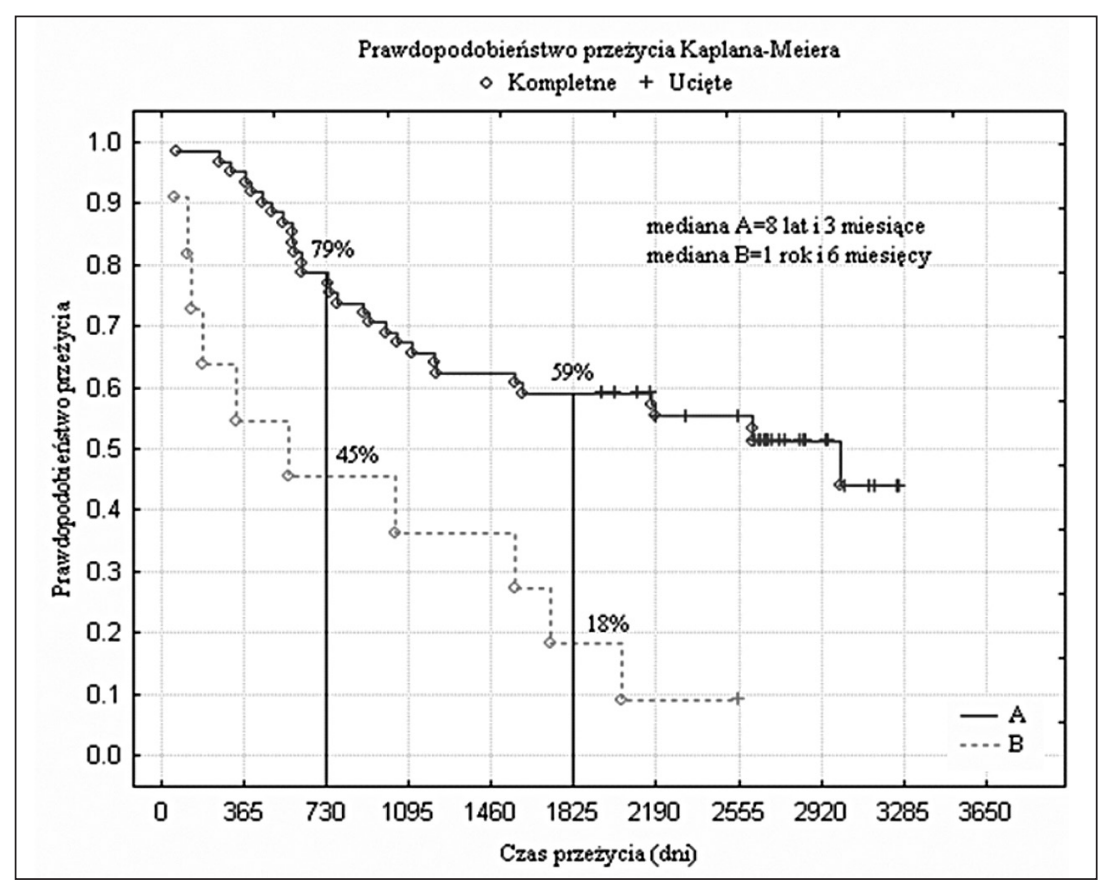

Rycina 5. Krzywe przeżycia całkowitego chorych leczonych radykalnie w stopniu zaawansowania klinicznego I-IV, u których zastosowano samodzielną radioterapię (A - 61 pacjentów w stopniu klinicznego zaawansowania I-II, B - 11 pacjentów w stopniu klinicznego zaawansowania III-IV)

(mediana przeżyć 8 lat i 3 miesiące), a w III-IV stopniu — odpowiednio 45\% i 18\% (mediana przeżyć 1 rok i 6 miesięcy) (różnice pomiędzy tymi grupami są istotne statystycznie; $p=0,004$ ) (ryc. 5). Tylko 1 pacjent z 8 chorych w stopniu zaawansowania klinicznego I-Il, u których zastosowano operację z uzupełniającą radioterapią, zmarł (kobieta lat 50, z za- awansowaniem klinicznym T2N0M0). Natomiast 2-i 5-letnie przeżycia całkowite pacjentów w stopniu zaawansowania klinicznego III-IV, u których zastosowano leczenie operacyjne i uzupełniającą radioterapię, wyniosły odpowiednio 60\% i 46\% (mediana przeżyć 3 lata i 10 miesięcy) (różnice pomiędzy tymi grupami są istotne statystycznie; $p=0,02$ ). 


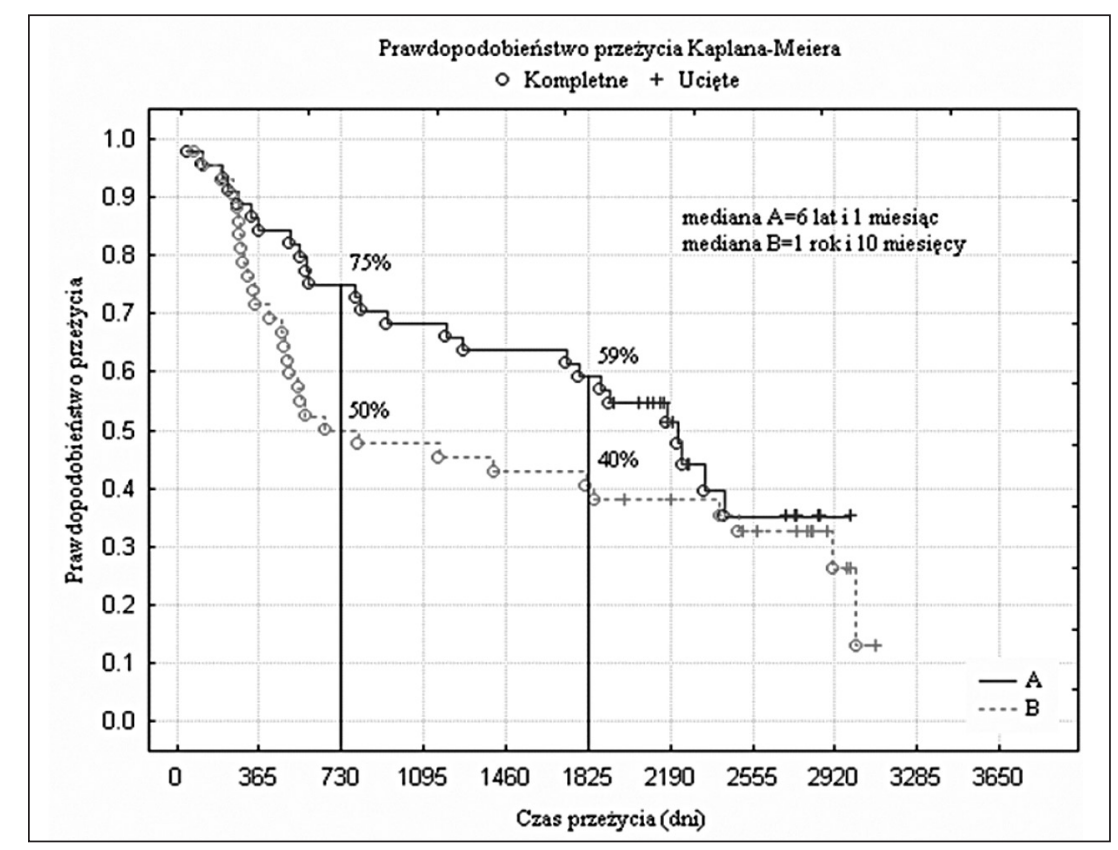

Rycina 6. Krzywe przeżycia całkowitego chorych leczonych radykalnie ze względu na cechę N(+) i N(-), u których zastosowano operację z uzupełniającą radioterapią (A - 44 pacjentów z cechą N(-), B - 42 pacjentów z cechą N(+))

Wykazano wpływ zajęcia węzłów chłonnych na całkowite przeżycia pacjentów leczonych radykalnie z powodu raka krtani. Dwu-i pięcioletnie przeżycia całkowite chorych z cechą N0 (67 pacjentów), u których zastosowano jedynie samodzielną radioterapię, wyniosły odpowiednio 76\% i 57\% (mediana przeżyć nieco ponad 7 lat). Natomiast nikt spośród 5 pacjentów tylko napromienianych, którzy mięli zajęte węzły chłonne (N1-3), nie przeżył 5 lat. Dwuletnie przeżycia całkowite chorych leczonych z cechą $\mathrm{N}(+)$ wyniosły 40\% (mediana przeżyć niespełna 1 rok) (różnice pomiędzy tymi grupami są znamienne statystycznie; $p=0,025$ ). Dwui pięcioletnie przeżycia całkowite pacjentów z cechą N0, u których zastosowano leczenie operacyjne z następową samodzielną radioterapią, wyniosły odpowiednio 75\% i 59\% (mediana przeżyć nieco ponad 6 lat). Dwu- i pięcioletnie przeżycia całkowite pacjentów po operacji i radioterapii z cechą N(+) wyniosły odpowiednio: 50\% i 40\% (mediana przeżyć niespełna 2 lata) (różnice pomiędzy tymi grupami nie są jednak znamienne statystycznie; $p=0,22$ ) (ryc. 6).

Przeprowadzono analizę porównawczą grupy osób leczonych radykalną radioterapią z powodu pooperacyjnej wznowy miejscowej wczesnej i późnej. Pacjenci leczeni napromienianiem ze względu na wznowę miejscową późną rokują lepiej. Dwu- i pięcioletnie przeżycia całkowite chorych leczonych z powodu późnej wznowy miejscowej wyniosły odpowiednio 55\% i 36\% (mediana przeżyć ponad 3 i pół roku) — OS tylko nieco niższe niż przeżycia wszystkich pacjentów leczonych radykalnie. Spośród 6 osób leczonych napromienianiem z powodu wczesnej wznowy miejscowej tylko 1 pacjent żyje nadal (kobieta lat 73, z zaawansowaniem klinicznym T2NOM0). Pozostałe osoby zmarły w ciągu kilkunastu miesięcy (mediana przeżyć 5 miesięcy) (test log-rank; $p=0,16)$ (rycina 7 - tylko w wersji elektronicznej).

Spośród 27 osób, którzy otrzymali paliatywną radioterapię, tylko 1 chory osiągnął długie przeżycie (3,7\% wszystkich leczonych paliatywnie) i żyje nadal (kobieta lat 53, z zaawansowaniem klinicznym T4NOM0). Siedemdziesiąt procent chorych leczonych z intencją paliatywną (19 pacjentów) zmarło w ciągu pierwszych 6 miesięcy od rozpoczęcia radioterapii, z czego w ciągu pierwszych 3 miesięcy zmarło $41 \%$ chorych (11 pacjentów) (mediana przeżyć 3,4 miesiąca).

\section{Analiza przyczyn niepowodzeń i zgonów}

Spośród 193 pacjentów leczonych radykalnie z powodu raka krtani w latach 2003-2006 do chwili obecnej żyją 73 osoby (65 osób żyje dłużej niż 3 lata od zakończenia leczenia i nie odnotowano u nich nawrotu miejscowego ani przerzutów odległych, 3 osoby żyją ze stwierdzoną wznową miejscową, jedna ze wznową miejscową i przerzutami odległymi oraz 4 osoby, które nie mają wznowy miejscowej ani przerzutów odległych, ale u których stwierdzono drugi pierwotny nowotwór). Wznowę miejscową stwierdzono u 25 chorych, z czego u 3 pacjentów wystąpiły także przerzuty odległe. Większość chorych ze wznową miejscową zmarło (21 pacjentów, 84\%), cztery osoby żyją nadal, pozostając w obserwacji w poradni laryngologicznej poza ośrodkiem onkologicznym. U 19 pacjentów, u których nie stwierdzono wznowy miejscowej, stwierdzono obecność przerzutów odległych. $U$ większości z tych chorych wystąpiły przerzuty do płuc (14 pacjentów, 74\%), w tym u 3 chorych także do 
innych narządów (mózg, kości, wątroba). Wszyscy pacjenci z przerzutami odległymi zmarli. Drugi pierwotny nowotwór stwierdzono u 17 osób. Najczęściej był to rak płuca (7 pacjentów, 41\%). Czterech pacjentów (24\%) zachorowało na drugi pierwotny nowotwór regionu głowy i szyi (rak wargi, rak języka, rak migdałka podniebiennego, rak gardła środkowego). Spośród pacjentów z drugim pierwotnym nowotworem nadal żyją 4 osoby (24\%).

Przyczyny śmierci pozostałych 67 pacjentów nie są do końca jasne.

Dziewiętnastu pacjentów zmarło w czasie do 8 miesięcy od zakończeniu leczenia, w tym 7 chorych w czasie pierwszych 3 miesięcy od zakończenia leczenia (5 pacjentów w ciągu pierwszego miesiąca od zakończenia leczenia, jeden pacjent przed upływem drugiego — i jeden przed upływem trzeciego miesiąca od zakończenia leczenia). Pięciu chorych było w wieku 69-78 lat, 2 młodszych chorych miało po 46 lat; tylko jeden pacjent otrzymał radiochemioterapię. Pacjenci zmarli prawdopodobnie z powodu powikłań leczenia (u wszystkich chorych obserwowano znaczny odczyn popromienny ze strony skóry i błon śluzowych). Jeden pacjent zmarł z powodu przetoki tchawiczo-przełykowej. Kolejnych 7 chorych zmarło z nieznanej przyczyny w czasie 4-8 miesięcy od zakończenia leczenia. Pacjenci ci zgłosili się co najmniej jeden raz do kontroli w tutejszym ośrodku i u żadnego z nich nie stwierdzono progresji choroby. Czterech chorych zmarłych w czasie od 4 do 8 miesięcy od zakończenia leczenia nigdy nie zgłosiło się do kontroli w tutejszym ośrodku.

Dziesięciu pacjentów zmarło z nieznanej przyczyny po ponad rocznej obserwacji. Wszyscy ci pacjenci kontrolowali się regularnie w tutejszym ośrodku, a ostatnia wizyta odbyła się w czasie nie dłuższym niż 3 miesiące przed zgonem i w jej trakcie nie stwierdzono cech progresji choroby. Trzydziestu ośmiu zmarłych pacjentów (żyli od roku i 3 miesięcy do 8 lat od zakończenia leczenia) nie kontrolowało się do końca życia w tutejszym ośrodku, ostatnią wizytę odbyli w czasie dłuższym niż 9 miesięcy przed śmiercią i w jej trakcie nie stwierdzono cech wznowy miejscowej ani przerzutów odległych (tab. IV).

\section{Omówienie}

Analiza wskaźników przeżyć odgrywa istotną rolę w ocenie skuteczności leczenia nowotworów złośliwych. Pozyskiwanie wiarygodnych danych o przeżyciach chorych na nowotwory w Europie jest możliwe dzięki bazie danych EUROCARE. W analizie EUROCARE-4, która objęła 23 państwa europejskie, średni odsetek dwu- i pięcioletnich przeżyć chorych na raka krtani zdiagnozowanego w latach 1995-1999 wyniósł odpowiednio 76\% i 63\% dla Polski i był on niższy od średniej, tj. 67\% i 50\% [2].

W przeprowadzonej analizie 220 chorych leczonych napromienianiem z powodu raka krtani w SP ZOZ MSW zW-
Tabela IV. Obserwacja 193 pacjentów poddanych radykalnemu leczeniu

\begin{tabular}{|c|c|c|c|}
\hline & Suma & Żyjący & Zgony \\
\hline Leczenie radykalne & 193 & 73 & 120 \\
\hline \multicolumn{4}{|l|}{1} \\
\hline $\begin{array}{l}\text { Pacjenci żyjący bez nawrotu choroby } \\
\text { i innego nowotworu }\end{array}$ & 65 & 65 & 0 \\
\hline \multicolumn{4}{|l|}{ ॥ } \\
\hline Niepowodzenie leczenia & 44 & 4 & 40 \\
\hline \multicolumn{4}{|l|}{ Wznowa miejscowa } \\
\hline tylko wznowa miejscowa & 22 & 3 & 19 \\
\hline $\begin{array}{l}\text { wznowa miejscowa i przerzuty odległe } \\
\text { (do kości, do płuca i wątroby, do skóry } \\
\text { klatki piersiowej) }\end{array}$ & 3 & 1 & 2 \\
\hline \multicolumn{4}{|l|}{ Przerzuty odległe } \\
\hline do płuc & 14 & 0 & 14 \\
\hline $\begin{array}{l}\text { inne: do mózgu (2), do wątroby (1), } \\
\text { do kości (1), do przełyku (1) }\end{array}$ & 5 & 0 & 5 \\
\hline \multicolumn{4}{|l|}{ III } \\
\hline Drugi nowotwór & 17 & 4 & 13 \\
\hline rak regionu głowy i szyi & 4 & 1 & 3 \\
\hline rak płuca & 7 & 2 & 5 \\
\hline $\begin{array}{l}\text { inne: rak żołądka (2), rak pęcherza } \\
\text { moczowego (2), rak odbytnicy (1), } \\
\text { rak przełyku i trzustki (1) }\end{array}$ & 6 & 1 & 5 \\
\hline \multicolumn{4}{|l|}{ IV } \\
\hline Pacjenci zmarli z nieznanej przyczyny & 67 & 0 & 67 \\
\hline
\end{tabular}

-MCO w Olsztynie w latach 2003-2006 przeżycia całkowite 2- i 5-letnie wszystkich pacjentów wyniosły odpowiednio 57\% i 43\%. Analiza nie objęła chorych we wczesnym stopniu zaawansowania klinicznego leczonych jedynie operacyjnie, w związku z tym przeżycia pacjentów przedstawione w pracy są gorsze niż średnie wskaźniki przytoczone dla Polski.

W przeprowadzonej w Centrum Onkologii w Warszawie analizie retrospektywnej obejmującej pacjentów z rozpoznaniem raka krtani, leczonych w latach 1989-1995 samodzielnie i radykalnie napromienianiem, wykazano istotny wpływ stopnia zaawansowania klinicznego na przeżycia chorych. Pacjenci analizowani byli pod względem cechy Ti N. Dwukrotnie wyższe ryzyko zgonu zaobserwowano w grupie chorych zarówno z zaawansowaniem klinicznym T3-T4, jak i chorych, którzy mieli zajęte węzły chłonne, niż w grupie pacjentów z zaawansowaniem klinicznym T1-T2 oraz z cechą No [3]. W Warmińsko-Mazurskim Centrum Onkologii także potwierdzono wpływ stopnia klinicznego zaawansowania na przeżycia leczonych pacjentów. Pięcioletnie przeżycia chorych leczonych samodzielną radioterapią w stopniu klinicznego zaawansowania I-II było znamiennie dłuższe w porównaniu ze stopniem III-IV (59\% vs 18\%). Istotnie lepsze przeżycia chorych uzyskano także w grupie chorych z cechą N0 (57\%) w porównaniu z grupą pacjentów, którzy mieli zajęte węzły chłonne (0\%). Pacjenci z cechą N(+) rokują 
najgorzej niezależnie od sposobu postępowania (samodzielna radioterapia, radiochemioterapia czy leczenie operacyjne uzupełnione radioterapią lub radiochemioterapią). Dla tych pacjentów mediany przeżyć całkowitych wynoszą od 0,5 do 2 lat (przy mOS dla wszystkich pacjentów leczonych radykalnie 4 lata i 9 miesięcy).

Wybór metody leczenia chorych na raka krtani zależy od lokalizacji nowotworu, stopnia zaawansowania klinicznego, stanu ogólnego chorego, chorób współistniejących oraz preferencji chorego [4-6]. Wyleczalność miejscowa raka krtani w stopniu zaawansowania T1-T2N0 po leczeniu operacyjnym lub samodzielnej radioterapii jest zbliżona [4, 5]. Wskaźniki 5-letnich przeżyć całkowitych pacjentów w stadium zaawansowania T1-T2N0 poddanych wyłącznie napromienianiu wynoszą 73-87\% [7-9], a pacjentów leczonych operacyjnie 77-92\% [9-13]. Niewątpliwym zyskiem leczenia napromienianiem jest zachowanie krtani [14-16]. W Warmińsko-Mazurskim Centrum Onkologii w latach 2003-2006 samodzielną radioterapią leczono 61 pacjentów z rakiem krtani w I i II stopniu klinicznego zaawansowania. 5-letnie przeżycia całkowite wyniosły 59\% i były niższe w porównaniu z przytoczonymi wskaźnikami z badań z randomizacją. Natomiast odsetek pacjentów żyjących 5 lat w li ll stopniu klinicznego zaawansowania (8 osób), którzy byli operowani, a następnie otrzymali uzupełniającą radioterapię, wyniósł $87,5 \%$, co jest zgodne z doniesieniami z literatury. W przypadku nowotworów głośni w stadium zaawansowania T1-T2N0 podnosi się rolę leczenia hypofrakcjonowanego. Przy zastosowaniu dawek frakcyjnych > 2 Gy zarówno kontrola miejscowa, jak i przeżycia 5-letnie są wyższe niż przy leczeniu konwencjonalnym [17-19]. W niniejszej analizie także zauważono tendencję do wydłużenia OS w przypadku stosowania dawki frakcyjnej 2,5-3 Gy (różnica nie była jednak znamienna statystycznie).

W stadium zaawansowania T3N0 raka górnego i środkowego piętra krtani leczeniem z wyboru jest radiochemioterapia lub leczenie operacyjne z uzupełniającą radioterapią. W stopniu zaawansowania T4 i w przypadku zajęcia węzłów chłonnych stosuje się leczenie operacyjne z uzupełniającą radioterapią [4-6]. Tian-Run i wsp. wykazali wpływ pooperacyjnej radioterapii na wydłużenie przeżycia pacjentów z zaawansowanym rakiem krtani leczonych chirurgicznie w stosunku do chorych, u których zastosowano wyłącznie resekcję (5-letnie OS wyniosły odpowiednio 52,3\% vs 49,6\%) [20]. Przeprowadzona analiza retrospektywna chorych leczonych w Śląskiej Akademii Medycznej w Katowicach z powodu raka krtani w stopniu III i IV klinicznego zaawansowania potwierdza to spostrzeżenie: wyższy odsetek przeżyć pacjentów leczonych operacyjnie z następowym napromienianiem w porównaniu z chorymi leczonymi wyłącznie chirurgicznie [21]. Według piśmiennictwa 5-letnie przeżycia chorych poddanych zabiegowi, a następnie napromienianiu, sięgają 50\% [13,22].
Jednoczasowa radiochemioterapia znajduje zastosowanie u chorych w stopniu zaawansowania III-IV, którzy nie kwalifikują się do zabiegu, a także w pooperacyjnym leczeniu pacjentów z niekorzystnymi czynnikami rokowniczymi (tj. liczne przerzuty w węzłach chłonnych szyi, przekraczanie przez naciek torebki węzła chłonnego) [4-6]. Wyniki przeprowadzonych badań z randomizacją wskazują na dłuższe przeżycia chorych poddanych jednoczasowej radiochemioterapii po zabiegu w porównaniu z grupą chorych leczonych uzupełniająco wyłącznie napromienianiem, pomimo częściej występujących efektów niepożądanych w przypadku stosowania metody skojarzonej [23-25]. W przypadku klinicznie niezajętych węzłów chłonnych (cN0) samodzielna radioterapia jest równie skuteczna jak poprzedzona operacją [26]. Niniejsza analiza także potwierdza to spostrzeżenie: przeżycia 2-i 5-letnie pacjentów bez przerzutów do węzłów chłonnych leczonych samodzielną radioterapią wyniosły odpowiednio $76 \%$ i $57 \%$, a pacjentów operowanych i następnie napromienianych odpowiednio $75 \%$ i 59\%.

Zastosowanie chemioterapii indukcyjnej nie poprawia wyników leczenia pomimo wcześniejszych obiecujących wyników badań [27]. Opublikowane ostatnio metaanalizy wskazują na większą skuteczność jednoczasowej radiochemioterapii w porównaniuz chemioterapią indukcyjną [28, 29]. W omawianej grupie 220 pacjentów leczonych napromienianiem tylko 2 pacjentów otrzymało chemioterapię indukcyjną przed radiochemioterapią. Byli to pacjenci ze wznową miejscową po operacji.

Większość pacjentów chorych na raka krtani w stopniu zaawansowania klinicznego III-IV leczona w SP ZOZ MSW z W-MCO w Olsztynie w latach 2003-2006 poddana została operacji, a następnie radioterapii. Pięcioletnie przeżycia całkowite w tej grupie chorych wyniosły $46 \%$. Najniższe przeżycia pacjentów w zaawansowanym stopniu klinicznym osiągnięto $w$ przypadku zastosowania samodzielnej radioterapii (5-letnie OS wyniosły 18\%).

\section{Wnioski}

Dwu- i pięcioletnie przeżycia całkowite chorych leczonych z intencją radykalną z powodu raka krtani w latach 2003-2006 w SP ZOZ MSW z W-MCO w Olsztynie wyniosły $65 \%$ i $48 \%$ (mediana przeżyć prawie 5 lat). Około połowa pacjentów była leczona operacyjnie z następową radioterapią lub radiochemioterapią. Większość chorych otrzymała standardową radioterapię, nie wykazano istotnych statystycznie różnic w przeżyciach całkowitych pacjentów leczonych metodą standardową i hypofrakcjonowaną. Przeżycia całkowite osób leczonych z rozpoznaniem raka krtani w niższym stopniu klinicznego zaawansowania były znamiennie dłuższe w porównaniu z OS chorych w stadiach bardziej zaawansowanych klinicznie. Pacjenci, którzy byli w stadium zaawansowania III-IV, ale nie mięli zajętych węzłów chłonnych, rokowali lepiej niż osoby z zajętymi węzłami 
chłonnymi. Chorzy z cechą $\mathrm{N}(+)$ rokują najgorzej niezależnie od zastosowanej metody leczenia (mediana OS 0,5-2 lat). Bardzo źle rokują także pacjenci leczeni z powodu wczesnej wznowy (mediana OS 0,5 roku).

\section{Prof. dr hab. n. med. Sergiusz Nawrocki}

Uniwersyteckie Centrum Okulistyki i Onkologii

ul. Ceglana 35, 40-952 Katowice

e-mail:sergiusz@cyberia.pl

Otrzymano: 5 sierpnia $2013 \mathrm{r}$.

Przyjęto do druku: 7 marca 2014 r.

\section{Piśmiennictwo}

1. Raporty na podstawie danych Centrum Onkologii http://85.128.14. $124 / \mathrm{krn} /$.

2. http://www.eurocare.it/DatabaseEU4/tabid/78/Default.aspx.

3. Hliniak A, Michalski W, Szutkowski Z i wsp. Radiotherapy outcomes in laryngeal cancer - a retrospective study. Nowotwory J Oncol 2002; 52: 111-117.

4. Ang KK, Garden AS. Radiotherapy for head and neck cancers indications and techniques. Wyd. 3. Philadelphia: Lippincott Williams \& Wilkins; 2006, s. 118-134.

5. Halperin EC, Peréz CA, Brady LW i wsp. Perez and Brady's principles and practice of radiation oncology. Philadelphia: Lippincott Williams \& Wilkins; 2008; s. 975-1034.

6. Kawecki A, Nawrocki S. Nowotwory nabłonkowe narządów głowy i szyi. W: Krzakowski M, Dziadziuszko R, Fijuth J i wsp. Zalecenia postępowania diagnostyczno-terapeutycznego w nowotworach złośliwych. Gdańsk:Via Medica; 2011; s. 1-32.

7. Mendenhall WM, Amdur RJ, Morris CG i wsp. T1-T2N0 squamous cell carcinoma of the glottic larynx treated with radiation therapy. J Clin Oncol 2001; 19: 4029-4036.

8. Garden AS, Forster K, Wong PF i wsp. Results of radiotherapy for T2N0 glottic carcinoma: does the "2" stand for twice-daily treatment? Int J Radiat Oncol Biol Phys 2003; 55: 322-328.

9. Jones AS, Fish B, Fenton JE i wsp. The treatment of early laryngeal cancers (T1-T2 N0): surgery or irradiation? Head Neck 2004; 26: 127-135.

10. Spector JG, Sessions DG, Chao KS i wsp. Stage I (T1 N0 M0) squamous cell carcinoma of the laryngeal glottis: therapeutic results and voice preservation. Head Neck 1999; 21: 707-717.

11. Thomas JV, Olsen KD, Neel HB i wsp. Early glottic carcinoma treated with open laryngeal procedures. Arch Otolaryngol Head Neck Surg 1994; 120 : 264-268.
12. Spector JG, Sessions DG, Chao KS i wsp. Management of stage II (T2NOM0) glottic carcinoma by radiotherapy and conservation surgery. Head Neck 1999; 21: 116-123.

13. Maurizi M, Almadori G, Cadoni G i wsp. Cathepsin D concentration in primary laryngeal cancer: correlation with clinico-pathological parameters, EGFR status and prognosis. Int J Cancer 1996; 69: 105-109.

14. Gall AM, Sessions DG, Ogura JH. Complications following surgery for cancer of the larynx and hypopharynx. Cancer 1977; 39: 624-631.

15. Bentz BG, Snyderman CH. Pulmonary complications in patients with head and neck and lung neoplasms. Arch Otolaryngol Head Neck Surg 2000; 126: 429-432.

16. Murray GM. Pulmonary complication following supraglottic laryngectomy. Clin Otolaryngol Allied Sci 1976; 1: 241-247.

17. Gultekin M, Ozyar E, Cengiz M i wsp. High daily fraction dose externa radiotherapy for $\mathrm{T} 1$ glottic carcinoma:Treatment results and prognostic factors. Head Neck 2012; 34: 1009-1014.

18. Nakamura K, Shioyama Y, Kawashima M i wsp. Multi-institutional analysis of early squamous cell carcinoma of the hypopharynx treated with radical radiotherapy. Int J Radiat Oncol Biol Phys 2006; 65: 1045-1050.

19. Karasawa $\mathrm{K}$, Kunogi $\mathrm{H}$, Hirai $\mathrm{T}$ i wsp. Radiotherapy with fraction size of 2.25 Gy in T1-2 laryngeal and hypopharyngeal cancer. J Radiat Res 2013; 54: 684-689.

20. Liu TR, Yang AK, Chen FJ i wsp. Survival and prognostic analysis of 221 patients with advanced laryngeal squamous cell carcinoma treated with surgery. Ai Zheng 2009; 28: 297-302.

21. Ligienza M. Wyniki leczenia raka krtani w materiale Katedry i Kliniki Laryngologii Śląskiej Akademii Medycznej w Katowicach w latach 1995-1999. Wydział Lekarski w Zabrzu 2006.

22. Gourin CG, Conger BT, Sheils WC i wsp. The effect of treatment on survival in patients with advanced laryngeal carcinoma. Laryngoscope 2009; 119: 1312-1317.

23. Bernier J, Domenge C, Ozsahin M i wsp. Postoperative irradiation with or without concomitant chemotherapy for locally advanced head and neck cancer. N Eng J Med 2004; 350: 1945-1952.

24. Bonner JA, Harari PM, Giralt Ji wsp. Radiotherapy plus cetuximab for squamous cell carcinoma of the head and neck. NEng JMed 2006; 354:567-578.

25. Cooper JS, Pajak TF, Forastiere AA i wsp. Postoperative concurrent radiotherapy and chemotherapy for high-risk squamous-cell carcinoma of the head and neck. N Eng J Med 2004; 350: 1937-1944.

26. Goudakos JK, Markou K, Nikolaou A i wsp. Management of the clinically negative neck (N0) of supraglottic laryngeal carcinoma: a systematic review. Eur J Surg Oncol 2009; 35: 223-229.

27. Induction chemotherapy plus radiation compared with surgery plus radiation in patients with advanced laryngeal cancer. The Department of Veterans Affairs Laryngeal Cancer Study Group. N Engl J Med 1991 324: $1685-1690$.

28. Pignon JP, le Maitre A, Maillard E i wsp. Meta-analysis of chemotherapy in head and neck cancer (MACH-NC): an update on 93 randomized trials and 17,346 patients. Radiother Oncol 2009; 92: 4-14.

29. Vokes EE. Induction chemotherapy for head and neck cancer: recent data. Oncologist 2010; 15 Suppl 3: 3-7. 
Tabela II. Podział pacjentów leczonych radykalnie ze względu na stopień zaawansowania klinicznego

\begin{tabular}{lcc}
\hline \multicolumn{3}{c}{ Wszyscy pacjenci leczeni radykalnie (193) } \\
\hline Stopień zaawansowania klinicznego & Liczba & $\%$ \\
\hline I & 47 & 24 \\
II & 30 & 16 \\
III & 39 & 20 \\
IV & 77 & 40 \\
\hline
\end{tabular}

Tabela III. Podział pacjentów leczonych radykalnie ze względu na cechę $\mathrm{N}(-/+)$

\begin{tabular}{lcc}
\hline \multicolumn{3}{c}{ Wszyscy pacjenci leczeni radykalnie (193) } \\
\hline Cecha N & Liczba & $\%$ \\
\hline N0 & 129 & 67 \\
N1 & 23 & 12 \\
N2 & 35 & 18 \\
N3 & 6 & 3 \\
\hline
\end{tabular}

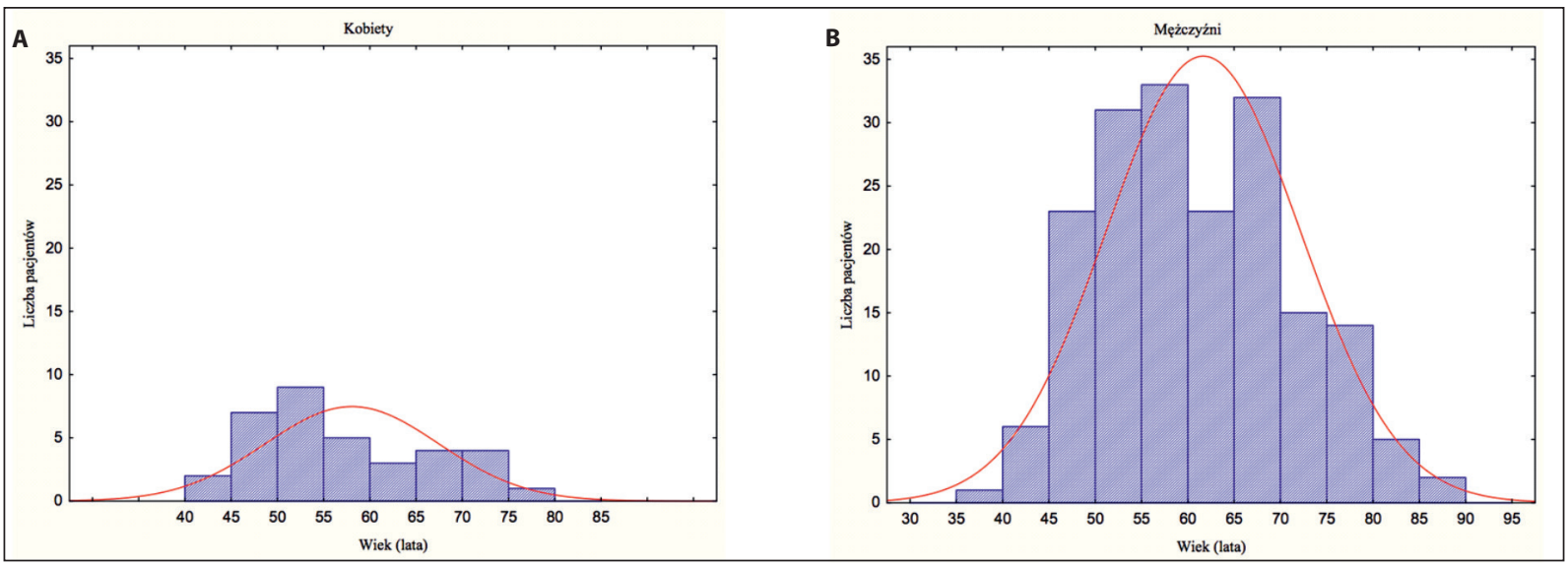

Rycina 1. Pacjenci leczeni napromienianiem z powodu raka krtani w SP ZOZ MSW z W-MCO w Olsztynie w latach 2003-2006 [kobiety (35) mężczyźni (185)]

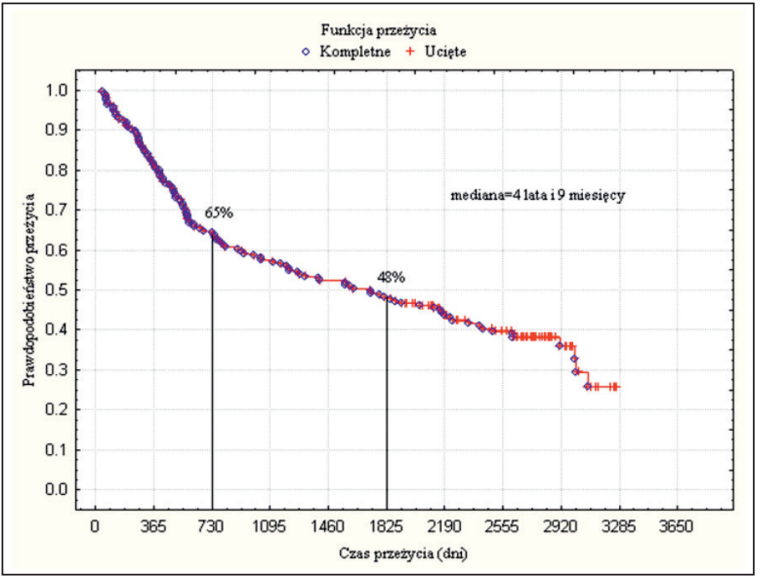

Rycina 3. Krzywa przeżycia całkowitego chorych leczonych radykalnie (193)

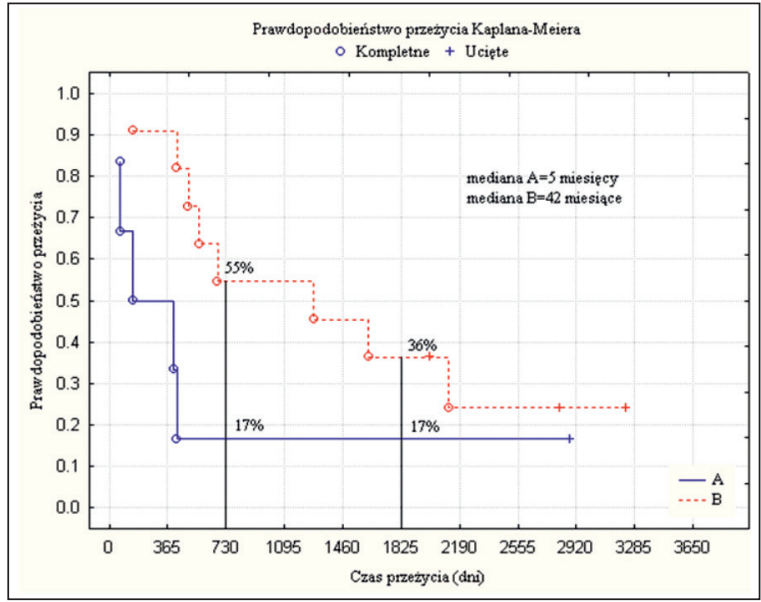

Rycina 7. Krzywe przeżycia całkowitego chorych leczonych radykalnie, którzy otrzymali napromienianie po operacji ze względu na wznowę miejscową (A - 6 pacjentów leczonych z powodu wznowy miejscowej wczesnej, B - 11 pacjentów leczonych z powodu wznowy miejscowej późnej) 